\title{
Analiza efektów zastosowania chemicznych metod trzecich wspomaganego wydobycia ropy na przykładzie złoża krajowego oparta na modelowaniu numerycznym
}

\author{
Analysis of the effects of tertiary EOR methods applied to a domestic oil reservoir from \\ numerical modelling
}

\author{
Wiesław Szott, Krzysztof Miłek \\ Instytut Nafty i Gazu - Państwowy Instytut Badawczy
}

\begin{abstract}
STRESZCZENIE: W pracy przedstawiono wyniki analizy zastosowania chemicznej metody wspomaganego wydobycia ropy wykorzystującej zatłaczanie do złoża roztworu polimeru i środka powierzchniowo czynnego (SPCz). Analizę tę przeprowadzono przy użyciu numerycznego modelowania procesów wypierania ropy z ośrodków porowatych. W modelowaniu tym uwzględniono wszystkie istotne zjawiska występujące $\mathrm{w}$ trakcie przepływów powyższych płynów $\mathrm{w}$ ośrodku porowatym, $\mathrm{w}$ szczególności: adsorpcję polimeru i SPCz na powierzchni porów skały złożowej, wpływ koncentracji polimeru i szybkości ścinania na efektywną lepkość wodnego roztworu wypierającego ropę, wpływ adsorpcji polimeru na redukcję przepuszczalności dla płynów złożowych, redukcję porowatości dostępnej dla cząsteczek polimeru, modyfikację napięcia międzyfazowego w układzie roztwory wodne-ropa spowodowaną obecnością środków powierzchniowo czynnych w roztworach. W rezultacie mechanizm wypierania ropy zatłaczanym roztworem przyjmuje złożony charakter, tzn. oprócz standardowej składowej wypierania niemieszającego ujawnia składową wypierania mieszającego, zależną od szczegółowych własności systemu: płyn wypierany-płyn wypierający-skała złożowa. Ze względu na złożony charakter powyższych zjawisk zachodzi potrzeba określenia ilościowych zależności istotnych właściwości chemikaliów od ich rodzaju i koncentracji w płynie wypierającym, co jest realizowane poprzez modelowanie procesów wypierania ropy w uproszczonych systemach próbek (układów rdzeni) skały złożowej. W tym celu skonstruowano modele badań laboratoryjnych na układzie rdzeni wiertniczych, na których odtworzono przebieg badań. Pozwoliło to na określenie ilościowych charakterystyk mechanizmów wypierania i zweryfikowało poprawność zastosowanego podejścia. Scharakteryzowane w ten sposób mechanizmy wypierania ropy zaimplementowano w numerycznym modelu rzeczywistego złoża krajowego. Przedstawiono uzyskane na tym modelu wyniki symulacji sczerpania ropy naftowej przy wykorzystaniu powyższych metod wykazujące ich korzystny wpływ na stopień sczerpania zasobów ropy. Otrzymano ilościowe wyniki dla różnych parametrów operacyjnych procesu wypierania ropy badanymi roztworami pozwalające ocenić efektywność stosowania analizowanych metod wspomaganego wydobycia ropy.
\end{abstract}

Słowa kluczowe: wspomagane wydobycie ropy, zatłaczanie związków chemicznych, polimery, środki powierzchniowo czynne, symulacje złożowe, mechanizmy wypierania.

ABSTRACT: The paper presents an analysis of the chemical EOR method utilising waterflooding with the use of a polymer and a surfactant solution. The analyse was carried out using numerical modelling of oil displacement processes from porous media. This modelling took into account all the significant phenomena occurring during the flow of the above fluids in the porous medium. It included polymer and surfactant adsorption on the surface of the rock pores; the impact of polymer concentration and shear rate on the effective viscosity of the displacing fluid; the effect of polymer adsorption on the reduction of permeability for reservoir fluids; the reduction of the porosity available for polymer particles; the modification of the interfacial tension in the aqueous solutions - oil system caused by the presence of a surfactant. As a result, the oil displacement mechanism with the injected solution becomes complex, i.e., in addition to the standard non-miscible displacement component, it reveals a miscible component depending on the specific properties of the system: displaced fluid - displacing fluid - reservoir rock. Due to the complex nature of the above phenomena, there is a need to determine the quantitative relationships for the significant properties of chemicals on their type and concentration in the displacing fluid. These relationships are obtained from modelling oil displacement processes in simplified systems of reservoir rock samples. For this purpose, models of laboratory tests were constructed for a system of drilling cores, on which the results of displacement tests were reproduced.

Autor do korespondencji: W. Szott, e-mail: wieslaw.szott@inig.pl

Artykuł nadesłano do Redakcji: 09.12.2019 r. Zatwierdzono do druku: 31.03.2020 r. 
This allowed the quantitative characteristics of displacement mechanisms to be determined and the correctness of the used approach to be verified. The oil displacement mechanisms characterized in this way were implemented in the numerical model of a real oil reservoir. The results of simulations for crude oil depletion using the above methods have been obtained in this model, showing their beneficial effect on the degree of depletion of oil resources. The dependents of production results on various operational parameters were obtained allowing to assess the effectiveness of the analysed methods for enhanced oil recovery.

Key words: EOR, chemical flooding, polymers, surfactants, reservoir simulations, displacement mechanisms.

\section{Wstęp}

Zatłaczanie chemikaliów (Mandal, 2015) do złoża ropy naftowej stanowi - obok zatłaczania płynów mieszających (dwutlenek węgla (Szott et al., 2012; Lubaś i Szott, 2012), azot (Wuensche, 1987), kondensat (Fath et al., 2016)) oraz metod termicznych (Mokheimer et al., 2019) - jedną z podstawowych tzw. metod trzecich (Felber, 2002) wspomaganego wydobycia ropy (Szott i Miłek, 2015), których głównym celem jest redukcja napięcia międzyfazowego na granicy woda-ropa i zwiększenie mobilności ropy, a w konsekwencji zwiększenie wyparcia ropy ze skały złożowej. Typowymi związkami chemicznymi zatłaczanymi do złoża są: polimery (Sheng et al., 2015) i środki powierzchniowo czynne (SPCz) (Oskarsson et al., 2005). Główną zaletą polimerów jest poprawa stosunku mobilności ropy do mobilności wody, co pociąga za sobą wzrost objęcia złoża procesami wypierania. Zatłaczanie SPCz powoduje redukcję napięcia międzyfazowego i zwiększony udział wypierania mieszającego (wypłukiwania) (Holm, 1986) w procesie wypierania ropy. Opis szczegółowych mechanizmów występujących podczas zatłaczania tych chemikaliów do złoża podano w kolejnych rozdziałach.

Ze względu na złożony charakter mechanizmów wypierania (Peters i Hardham, 1986) ropy wodnymi roztworami chemikaliów, wymagający określenia ilościowych zależności istotnych właściwości chemikaliów od ich rodzaju i koncentracji w płynie wypierającym, modelowanie efektów zastosowania metod chemicznych na przykładzie rzeczywistego złoża ropy naftowej musi być poprzedzone analizą tych mechanizmów w uproszczonych systemach próbek (układów rdzeni) skały złożowej. Analiza taka pozwala lepiej zrozumieć i scharakteryzować mikroskopowe charakterystyki mechanizmów wypierania ropy. Analiza wyników laboratoryjnych eksperymentów wypierania ropy za pomocą numerycznych modeli badanych systemów próbek skały złożowej w praktyce światowej (Gu et al., 2013) stanowi standardowe podejście do omawianego zagadnienia. W literaturze krajowej według najlepszej wiedzy autorów brak jest tego typu analiz w odniesieniu do chemicznych metod trzecich w warunkach złóż krajowych.

W pracy przedstawiono wyniki analizy tych mechanizmów, wykorzystując modele symulacyjne układu rdzeni wiertniczych oraz wyniki eksperymentów laboratoryjnych pozwalające na dookreślenie brakujących charakterystyk mechanizmów wypierania oraz na ocenę wiarygodności modeli w procesie ich kalibracji. W kolejnym etapie realizacji pracy przeprowadzono modelowanie efektów zastosowania chemicznych metod trzecich wspomaganego wydobycia ropy naftowej na przykładzie krajowego złoża ropnego.

W pracy wykorzystano symulator Eclipse ${ }^{\circledR} 100$ oraz pakiet Petrel ${ }^{\circledR} 2015$ do pre- i postprocessingu danych wejściowych i wyników symulacji.

\section{Analiza procesów wypierania ropy przy użyciu wodnych roztworów polimerów i SPCz na modelu systemu rdzeni wiertniczych}

W niniejszym rozdziale przedstawiono wyniki symulacji procesów wypierania ropy roztworem polimeru i $\mathrm{SPCz}$ (Wilk et al., 2019) przeprowadzonych na modelu systemu rdzeni wiertniczych, na którym wykonano badania laboratoryjne wypierania ropy wodnymi roztworami polimeru i SPCz. Model ten skonstruowano, uwzględniając znaną charakterystykę rdzeni (rozmiary geometryczne, porowatość, przepuszczalność absolutną, początkowe nasycenie płynami złożowymi) oraz właściwości płynów złożowych i płynów zatłaczanych. Użyto jednowymiarowego modelu o dużej rozdzielczości wzdłuż rdzeni (100 bloków o długości około $0,1 \mathrm{~cm}$ ). Pomiary eksperymentalne obejmowały: wydajność tłoczenia płynów do rdzeni, ciśnienie na wlocie i wylocie systemu, wydajność i sumaryczny wypływ ropy i roztworu wodnego. Charakterystykę systemu rdzeni oraz przebiegu eksperymentu podano w tabeli 1. Rdzenie użyte w eksperymencie zostały pobrane z jednego z krajowych złóż ropnych, w którym skałę zbiornikową stanowią węglany dolomitu głównego i dla którego przeprowadzono symulacje opisane w dalszych rozdziałach. W eksperymencie wyróżniono dwie fazy: faza I to okres zatłaczania solanki bez dodatku chemikaliów, faza II to okres zatłaczania solanki z zawartością polimeru i SPCz.

Wyniki tych pomiarów posłużyły do kalibracji modelu numerycznego, a w szczególności do uzupełnienia właściwości transportowych systemu, takich jak: przepuszczalności względne dla ropy i roztworu wodnego, adsorpcja polimeru i SPCz, napięcie międzyfazowe w systemie roztwór wodny-ropa i innych, opisanych poniżej. 
Tabela 1. Charakterystyka eksperymentu służącego do kalibracji modelu

Table 1. Characteristics of the experiment used to calibrate the model

\begin{tabular}{|c|c|c|c|}
\hline \multirow{2}{*}{ Grupa parametrów } & \multirow{2}{*}{ Wielkość } & \multicolumn{2}{|c|}{ Wartość } \\
\hline & & rdzeń nr 1 & rdzeń nr 2 \\
\hline \multirow{5}{*}{ Podstawowe charakterystyki rdzeni } & długość [cm] & 4,903 & 5,096 \\
\hline & pole przekroju poprzecznego $\left[\mathrm{cm}^{2}\right]$ & 8,84 & 8,84 \\
\hline & porowatość [-] & 0,1331 & 0,1247 \\
\hline & przepuszczalność absolutna [mD] & 228,72 & 30,74 \\
\hline & objętość porów PV $\left[\mathrm{cm}^{3}\right]$ & 6,325 & 6,147 \\
\hline \multirow{3}{*}{ Wydajność tłoczenia [ml/min] } & faza I: solanka & \multicolumn{2}{|c|}{0,1} \\
\hline & faza II: solanka + polimer $+\mathrm{SPCz}$ & \multicolumn{2}{|c|}{0,1} \\
\hline & szybkość ścinania dla polimeru $[1 / \mathrm{s}]$ & 12,03 & 33,99 \\
\hline \multirow{4}{*}{$\begin{array}{l}\text { Koncentracja składnika w zatłaczanym } \\
\text { płynie }\left[\mathrm{g} / \mathrm{cm}^{3}\right]\end{array}$} & faza I: solanka & \multicolumn{2}{|c|}{0,337} \\
\hline & faza II: solanka & \multicolumn{2}{|c|}{0,337} \\
\hline & faza II: polimer & \multicolumn{2}{|c|}{0,003} \\
\hline & faza II: SPCz & \multicolumn{2}{|c|}{0,005} \\
\hline \multirow{3}{*}{ Przyrost ciśnienia, Pin-Pout [atm] } & początkowy & \multicolumn{2}{|c|}{1,32} \\
\hline & faza I: plateau & \multicolumn{2}{|c|}{0,04} \\
\hline & faza II: plateau & \multicolumn{2}{|c|}{0,90} \\
\hline \multirow{9}{*}{ Sumaryczny wypływ $\left[\mathrm{cm}^{3}\right]$} & faza I: solanka & \multicolumn{2}{|c|}{25,00} \\
\hline & faza I: ropa naftowa & \multicolumn{2}{|c|}{2,70} \\
\hline & faza II: solanka & \multicolumn{2}{|c|}{58,00} \\
\hline & faza II: ropa naftowa & \multicolumn{2}{|c|}{3,40} \\
\hline & czas I fazy [h] & \multicolumn{2}{|c|}{4,67} \\
\hline & ilość zatłoczonego roztworu [krotność PV] & \multicolumn{2}{|c|}{5,00} \\
\hline & całkowity czas tłoczenia [min] & \multicolumn{2}{|c|}{623,0} \\
\hline & początkowe nasycenie ropą, $S_{\text {oini }}$ & \multicolumn{2}{|c|}{0,4971} \\
\hline & udział wypierania niemieszającego w odropieniu rdzeni [\%] & \multicolumn{2}{|c|}{24,26} \\
\hline
\end{tabular}

\section{Mechanizmy wypierania ropy wodnymi roztworami polimeru i środka powierzchniowo czynnego}

W procesie modelowania zjawisk wypierania ropy w ośrodku porowatym roztworami SPCz i polimeru uwzględniono dwa podstawowe mechanizmy: wypieranie niemieszające i wypieranie mieszające.

Wypieranie niemieszające (Ruben i Patzek, 2002) - scharakteryzowane jest obecnością zróżnicowanych faz roztworu wodnego i ropy i opisane krzywymi przepuszczalności względnych $k_{r w / o}$, jako funkcji nasyceń roztworu wodnego $S_{w}$ oraz ropy, $S_{o}$, o postaci:

$$
k_{r w / o}=k_{r w / o, \max }\left[C_{1}\left(S_{w / o}^{*}\right)^{\beta}+C_{2}\left(S_{w / o}^{*}\right)^{\alpha}\right]
$$

gdzie:

$k_{r w /, m a x}$ - maksymalna przepuszczalność względna dla $S_{w / o}^{*}=1$, $S_{w / o}^{*}=\frac{S_{w / o}-S_{w / o, r}}{S_{w / o, \max }-S_{w / o, r}}-$ zredukowane nasycenie roztworu wodnego/ropy,

$S_{w /, r}-$ resztkowe nasycenie roztworu wodnego/ropy,
$S_{w / o, \max }$ - maksymalne nasycenie roztworu wodnego/ropy, $C_{1}, C_{2}$ - wagi poszczególnych członów: $C_{1}=C\left(S_{w / o}^{*}\right)^{\gamma}$, $C_{2}=1-C_{1}$.

Parametry $k_{r w / o, \max }, S_{w / o, r}, S_{w / o, \max }, C, \alpha, \beta, \gamma-$ to parametry swobodne modelu.

W praktyce popartej doświadczeniem z kalibracji modeli użyto następujących wartości:

$$
k_{r w /, \text { max }}=1, S_{w, \max }=1, S_{o, \max }=1-S_{w r}=0,15
$$

Pozostałe parametry tzn. $S_{o r}, C, \alpha, \beta, \gamma$ podlegały modyfikacji w procesie kalibracji modelu.

Wypieranie mieszające (Jankovic, 1986; Szott, 2007, 2012) - scharakteryzowane jest zanikiem napięcia międzyfazowego i opisane liniową efektywną przepuszczalnością względną $k_{r w / 0}\left(S_{w / o}^{*}\right)$, tzn. według wzoru (1) dla:

$$
S_{w / o, r}=0, S_{w /, \max }=1, \gamma=\alpha=0, \beta=1
$$

Mechanizmy te są efektem szczegółowych zjawisk transportu wynikających z obecności polimeru i SPCz. W analizowanych eksperymentach wypierania ropy powyższe mechanizmy 
obejmują również zjawiska szczegółowe opisane poniżej. Obecność polimeru w roztworze wypierającego płynu prowadzi do następujących zjawisk:

- wzrostu lepkości roztworu, $\mu_{p}$, zależnej od koncentracji polimeru $C_{p}$, szybkości ścinania $\gamma$, i temperatury $T$ - użyto zależności Ellisa i Carreau (Sochi, 2009):

$$
\mu_{p}=K \gamma^{n}
$$

gdzie: $\ln K=a+b \ln C_{p}+c T, \ln n=d+e \ln C_{p}+f T$, gdzie współczynniki $a, b, c, d, e, f$ wyznaczono z dopasowania powyższych zależności do danych eksperymentalnych;

- adsorpcji polimeru $C_{p}^{a}$ (Ong et al., 2019), w funkcji jego koncentracji $C_{p}$, według zależności:

$$
C_{p}{ }^{a}=\frac{a\left(C_{r}\right)^{m}}{1+b C_{r}}
$$

$C_{r}=\frac{C_{p}-C_{c r i t}}{C_{\max }-C_{c r i t}}$ dla $C_{p}$ powyżej koncentracji krytycznej, $C_{p}>C_{c r i t}$ gdzie: - to zredukowana koncentracja polimeru w roztworze; parametry $a, b, m$ wyznaczone w procesie kalibracji modelu;

- redukcji przepuszczalności bezwzględnej $k$, do wartości $k_{p}=k / R_{k}$ w efekcie adsorpcji polimeru (Mishra et al., 2014) według zależności:

$$
R_{k}=1+(R R F-1) \frac{C_{p}^{a}}{C_{p}^{a, \max }}
$$

gdzie: $R R F$ - to tzw. czynnik oporu resztkowego $(R R F \geq 1)$, $C_{p}^{a, \max }$ - to maksymalna wielkość adsorpcji polimeru. $R R F$ i $C_{p}^{a, m a x}$ wyznaczone w procesie kalibracji modelu;

- redukcji efektywnej porowatości, $\phi_{p}$ (Xiong et al., 2018), dostępnej dla polimeru:

$$
\phi_{p}=\phi\left(1-S_{d}\right)
$$

gdzie: $S_{d}$ - to parametr tzw. martwej objętości porów dla polimeru wyznaczony w procesie kalibracji modelu.

Obecność SPCz w roztworze wypierającego płynu prowadzi do następujących zjawisk:

- adsorpcji SPCz w ośrodku porowatym, $C_{e}^{a}$ (Delshad et al., 2013), w funkcji jego koncentracji, $C_{e}$, w roztworze: użyto zależności analogicznej do adsorpcji polimeru;

- zmiany napięcia międzyfazowego (ropa-roztwór SPCz) $\sigma$, w funkcji koncentracji SPCz, $C_{e}$ : użyto zależności:

$$
\sigma=\sigma_{0}-a \ln \left(1+b C_{e}\right)
$$

gdzie parametry $\sigma_{0}, a \mathrm{i} b$ wyznaczono poprzez dopasowanie powyższej zależności do wielkości zmierzonych (Golabi, 2014) w warunkach laboratoryjnych;

- modyfikacji resztkowych nasyceń ropy $S_{o r}$ (Moreno et al., 2011), i roztworu SPCz, $S_{w r}$, w funkcji udziału wypierania mieszającego:

$$
S_{o / w, r}{ }^{e f f}=\left(1-\mathrm{F}_{\text {misc }}\right) S_{o / w, r}{ }^{i m m i s c}
$$

gdzie: $S_{o / w, r}{ }^{i m m i s c}$ - to resztkowe nasycenie ropy/wody dla wypierania niemieszającego, a funkcja $F_{\text {misc }}$ jest zdefiniowana poniżej;

- modyfikacji efektywnych przepuszczalności względnych (Alzayer et al., 2016) ropy $k_{r o}{ }^{e f f}$, i roztworu SPCz, $k_{r w}{ }^{e f f}$, w funkcji udziału wypierania mieszającego:

$k_{r o / \underline{\mathrm{w}}}^{\underline{e f f}}=F_{m i s c} \cdot k_{r o / w}^{\text {misc }}\left(S_{o / w}\right)+\left[1-F_{m i s c}\right] \cdot k_{r o / w}^{i m m i s c}\left(S_{o / w}\right)$

gdzie: $k_{\text {ro/w }}{ }^{\text {miscimmisc }}$ - to funkcja przepuszczalności względnej wypierania mieszającego/niemieszającego przeskalowana do wypierania resztkowego, $S_{o / w, r}$ eff;

- $\quad$ powyższe modyfikacje zależą od funkcji $F_{\text {misc }}$, interpolującej efektywne wypieranie pomiędzy wypieraniem mieszającym i niemieszającym w zależności od liczby kapilarnej $N_{c}$ (Guo et al., 2017), przepływu płynów złożowych $\left(N_{c}=\frac{k|\nabla P|}{\sigma}\right.$, gdzie $k$ - przepuszczalność ośrodka, $\nabla P$ - gradient ciśnienia, a $\sigma$-napięcie międzyfazowe wprowadzone powyżej):

$$
F_{\text {misc }}\left(x=\log N_{c}\right)=\frac{\exp \left\{\left(x-x_{0}\right) / a\right\}}{\exp \left\{\left(x-x_{0}\right) / a\right\}+\exp \left\{-\left(x-x_{0}\right) / a\right\}}
$$

gdzie: $x_{0}=\log N_{c, c r i t}-$ jest logarytmem granicznej liczby kapilarnej, $N_{c, \text { crit }}$, rozdzielającej przedział wypierania mieszającego od niemieszającego, $a$ - jest szerokością przedziału pośredniego. Funkcja $F_{\text {misc }}$ przyjmuje wartość 1 (wypieranie czysto mieszające) dla dużych liczb kapilarnych $\left(N_{c}>N_{c, c r i t}\right.$ ) oraz wartość 0 (wypieranie czysto niemieszające) dla małych liczb kapilarnych $\left(N_{c}>N_{c, \text { crit }}\right)$.

W efekcie wykorzystano minimalny zestaw modeli opisujących wszystkie istotne zjawiska zachodzące podczas wypierania ropy roztworami polimeru i SPCz. Nieokreślone parametry tych modeli były traktowane jako parametry swobodne w opisanym poniżej procesie kalibracji całościowego modelu użytego do odtworzenia badania eksperymentalnego wypierania ropy powyższymi roztworami. Kalibracja ta była prowadzona iteracyjną metodą systematycznych zmian wartości parametrów swobodnych modelu.

\section{Wyniki kalibracji modelu}

W opisywanym eksperymencie użyto następujących płynów: ropy naftowej, solanki złożowej, solanki zatłaczanej z roztworem polimeru i SPCz. Właściwości ropy naftowej scharakteryzowano znanym współczynnikiem objętościowym $B_{o}$, rozpuszczalnością $R_{s}$, gazu w ropie, gęstością $\rho_{o}$, oraz 
lepkością $\mu_{o}$, w warunkach złożowych wyznaczonych za pomocą termodynamicznego modelu ropy według równania stanu Soave-Redlicha-Kwonga przy użyciu programu PVTSim $^{\circledR}$ na podstawie pomiarów własnych jej składu i właściwości PVT. Właściwości termodynamiczne roztworów wodnych określono w oparciu o standardowe korelacje zależności gęstości roztworu od temperatury, ciśnienia, zasolenia i zawartości rozpuszczonego gazu. Analogicznie wyznaczono lepkość solanki bez zawartości polimeru.

Symulacje laboratoryjnych eksperymentów wypierania ropy z zestawu rdzeni przeprowadzono, zadając wydajność i skład zatłaczanego płynu oraz ciśnienie na wylocie zestawu rdzeni. W procesie kalibracji modelu porównywano wyniki pomiarów z wynikami symulacji dla: ciśnienia na wlocie rdzeni, wypływu ropy i roztworu wodnego. Końcowe efekty kalibracji modelu dla tych wielkości przedstawiono na rysunkach 1, 2, 3, uzyskując bardzo dobre dopasowanie wyników symulacji do wyników pomiarów. Warto zauważyć gwałtowny przyrost ciśnienia na wlocie układu rdzeni z chwilą rozpoczęcia II fazy tłoczenia (roztworu polimeru i SPCz), wynikający ze zwiększonych oporów zatłaczania płynu o dużej lepkości, zdeterminowanej obecnością polimeru.

W wyniku procesu kalibracji modelu otrzymano wartości ww. parametrów swobodnych podane w tabeli 2 .

Analizowany eksperyment pozwala bezpośrednio (z pomiarów) wyznaczyć udział wypierania niemieszającego (z zasobów pierwotnych i sumarycznego wydobycia ropy) w procesie całkowitego odzyskiwania ropy z rdzeni. Udział ten wynosi $24,3 \%$. Pozostałe parametry modelu dopuszczają pewne zakresy zmienności, przedstawione poniżej. Alternatywne modele symulacyjne prowadzą do wyników odtwarzających pomiary przebiegu ciśnień na wlocie eksperymentu oraz wypływu ropy. Wyniki dla wypływu wodnego roztworu polimeru i SPCz wykazują jedynie minimalne zróżnicowanie dla poszczególnych wariantów i dlatego odpowiadają im wyniki przedstawione na rysunku 3 . Analizowane warianty wykazały niejednoznaczność w szczególności dwóch parametrów modelu: (i) resztkowego nasycenia ropą $S_{\text {or }}$, zmieniającego się w zakresie $0,020-0,262$ w pierwszym rdzeniu oraz $0,262-0,497$ w drugim rdzeniu, (ii) parametru $x_{0} \mathrm{w}$ funkcji interpolacyjnej $F_{\text {misc }}\left(N_{c}\right)$, zmieniającego się w zakresie: $(-4,00)-(-4,05)$. Szczegółowe wnioski z tej analizy wykraczają poza zakres niniejszej pracy i zostaną przedstawione $\mathrm{w}$ oddzielnej publikacji.

Przeprowadzone badania symulacyjne pozwoliły pozytywnie zweryfikować możliwości modelowania analizowanych procesów za pomocą użytych narzędzi programistycznych z uwzględnieniem istotnych mechanizmów determinujących te procesy. Umożliwiły również określenie ilościowych charakterystyk wszystkich tych mechanizmów. W rezultacie otrzymano kompletny zestaw danych wejściowych koniecznych

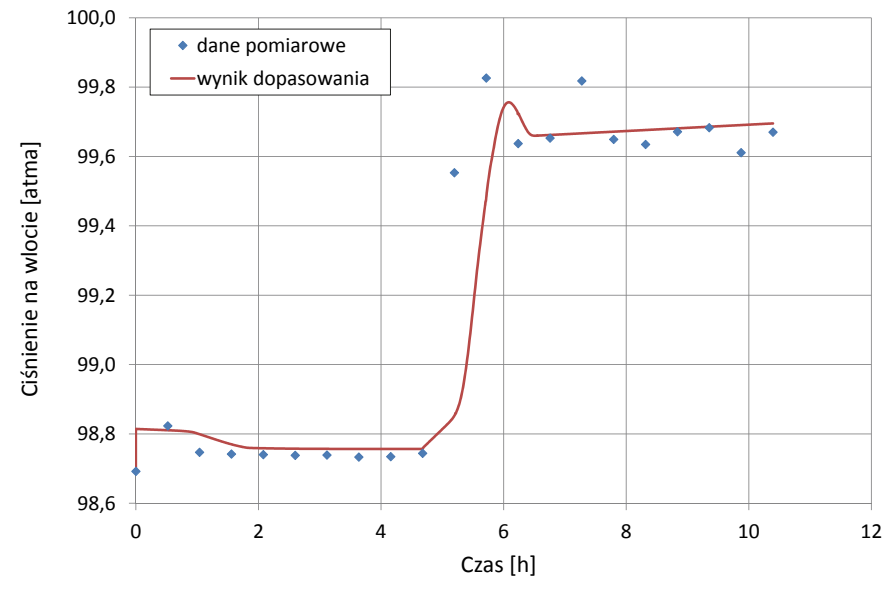

Rys. 1. Przebieg ciśnienia na wlocie zestawu rdzeni. Pomiar vs wyniki symulacji: średni kwadratowy błąd dopasowania $\sigma=0,05 \mathrm{~atm}$ (po odrzuceniu 2 punktów odstających - outliers)

Fig. 1. Pressure curve at the inlet of the core set. Measurement vs. simulation results: mean square error $\sigma=0.05 \mathrm{~atm}$. (after rejecting 2 outliers)

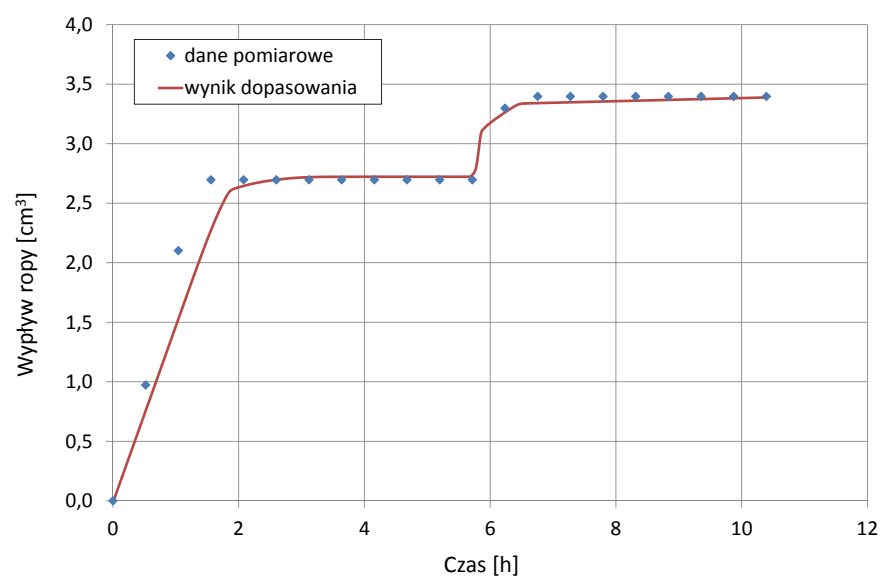

Rys. 2. Przebieg sumarycznego wypływu ropy z zestawu rdzeni. Pomiar vs wyniki symulacji: średni kwadratowy błąd dopasowania $\sigma=0,16 \mathrm{~cm}^{3}$

Fig. 2. Total oil outflow from the core set vs time. Measurement vs. simulation results: mean square error $\sigma=0.16 \mathrm{~cm}^{3}$

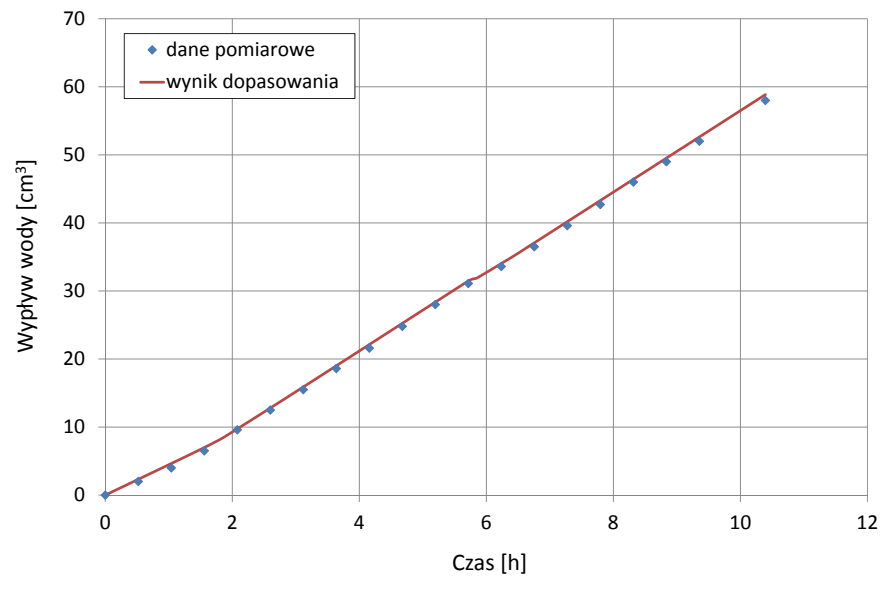

Rys. 3. Przebieg sumarycznego wypływu roztworu wodnego z zestawu rdzeni. Pomiar vs wyniki symulacji: średni kwadratowy błąd dopasowania $\sigma=0,48 \mathrm{~cm}^{3}$

Fig. 3. Total outflow of the aqueous solution from the core set vs. time. Measurement vs. simulation results: mean square error $\sigma=0.48 \mathrm{~cm}^{3}$ 
Tabela 2. Parametry skalibrowanego modelu wypierania ropy roztworem polimeru i SPCz Table 2. Parameters of the calibrated model of oil displacement with the use of the polymer and the surfactant solution

\begin{tabular}{|c|c|c|c|}
\hline \multirow{2}{*}{ Model } & \multirow{2}{*}{$\begin{array}{l}\text { Parametr } \\
\text { modelu }\end{array}$} & \multicolumn{2}{|c|}{ Wartość } \\
\hline & & rdzeń nr 1 & rdzeń nr 2 \\
\hline \multirow{4}{*}{$\begin{array}{l}\text { przepuszczalności względnych wody } \\
\text { dla wypierania mieszającego, równa- } \\
\text { nia (1) i (3) }\end{array}$} & $\alpha$ & 0,00 & 0,00 \\
\hline & $\beta$ & 1,00 & 1,00 \\
\hline & $\gamma$ & 0,00 & 0,00 \\
\hline & $C$ & 0,70 & 0,70 \\
\hline \multirow{5}{*}{$\begin{array}{l}\text { przepuszczalności względnych ropy } \\
\text { dla wypierania niemieszającego, rów- } \\
\text { nania (1) i (2) }\end{array}$} & $S_{o r}$ & 0,262 & 0,262 \\
\hline & $\alpha$ & 1,40 & 1,40 \\
\hline & $\beta$ & 1,50 & 1,50 \\
\hline & $\gamma$ & 0,12 & 0,12 \\
\hline & $C$ & 0,10 & 0,10 \\
\hline \multirow{5}{*}{ adsorpcji polimeru, równanie (5) } & $a$ & $1,0 \mathrm{E}-02$ & $1,0 \mathrm{E}-02$ \\
\hline & $b$ & 0,00 & 0,00 \\
\hline & $m$ & 1,00 & 1,00 \\
\hline & $C_{p, \text { crit }}$ & $1,1 \mathrm{E}-3$ & $1,1 \mathrm{E}-3$ \\
\hline & $C_{p, \max }$ & \multicolumn{2}{|c|}{0,005} \\
\hline \multirow{3}{*}{$\begin{array}{l}\text { redukcji przepuszczalności absolutnej, } \\
\text { równanie (6), i porowatości, równanie (7) }\end{array}$} & $R R F$ & 1,00 & 1,00 \\
\hline & $C_{a}\left(C_{p, \max }\right)$ & $1,00 \mathrm{E}-02$ & $1,00 \mathrm{E}-02$ \\
\hline & $S_{d}$ & 0 & 0 \\
\hline \multirow{5}{*}{ adsorpcji SPCz, równanie (5) } & $a$ & $5,01 \mathrm{E}-05$ & $5,01 \mathrm{E}-05$ \\
\hline & $b$ & $5,00 \mathrm{E}-03$ & $5,00 \mathrm{E}-03$ \\
\hline & $m$ & 0,99 & 0,99 \\
\hline & $C_{e, c r i t}$ & $2,00 \mathrm{E}-05$ & $2,00 \mathrm{E}-05$ \\
\hline & $C_{e, \max }$ & \multicolumn{2}{|c|}{$5,00 \mathrm{E}-03$} \\
\hline \multirow{2}{*}{$\begin{array}{l}\text { funkcji interpolacyjnej } F_{\text {misc }}\left(N_{c}\right) \text {, równa- } \\
\text { nie (11) }\end{array}$} & $x_{0}$ & \multicolumn{2}{|c|}{$-4,050$} \\
\hline & $a$ & \multicolumn{2}{|c|}{1,000} \\
\hline
\end{tabular}

wartości $34 \mathrm{mD}$ zmienia się w szerokich granicach 1-100 mD. Warstwy zbiornikowe złoża, o średniej miąższości około $45 \mathrm{~m}$, zalegają na głębokości 3180 m p.p.m. Odpowiada to początkowym warunkom złożowym: temperaturze $T=127^{\circ} \mathrm{C}$ i ciśnieniu 426 bar. Na obszarze całego złoża występuje woda podścielająca, natomiast niewielka czapa gazowa jest obecna tylko w peryferyjnej, północno-zachodniej części złoża. Model złoża typu pojedynczej porowatości składa się z ponad 25000 bloków o średnich rozmiarach $100 \times 100 \times 3 \mathrm{~m}$ ułożonych w 15 warstw. Całkowita objętość porów modelu to $76 \mathrm{mln}^{3}$. Średnie nasycenie ropą w warstwach roponośnych wynosi $S_{o}=0,840$. Widok modelu złoża przedstawiono na rysunku 4.

\section{Podstawowe założenia procesu zatłaczania roztworów chemicznych do złoża}

W analizowanym modelu wypierania ropy zastosowano tzw. odwrócony schemat pięciopunktowy, tzn. zlokalizowano cztery odwierty zatłaczające w narożach regularnego czworoboku z odwiertem wydobywczym w jego środku (rys. 5). do symulacji procesów wypierania ropy naftowej roztworami polimeru i SPCz na wielkoskalowych modelach złożowych.

\section{Symulacje procesów wspomaganego wydobycia ropy metodą zatłaczania SPCz i polimeru na modelu złoża ropnego}

\section{Charakterystyka modelu złoża}

Do symulacyjnych badań procesów wspomaganego wydobycia ropy metodą zatłaczania $\mathrm{SPCz}$ i polimeru wykorzystano istniejący model krajowego złoża ropnego. Złoże to zlokalizowane jest w utworach barierowych dolomitu głównego. Porowatość skały złożowej o średniej wartości 16\% zmienia się w granicach około 10-22\%, a jej przepuszczalność absolutna o średniej

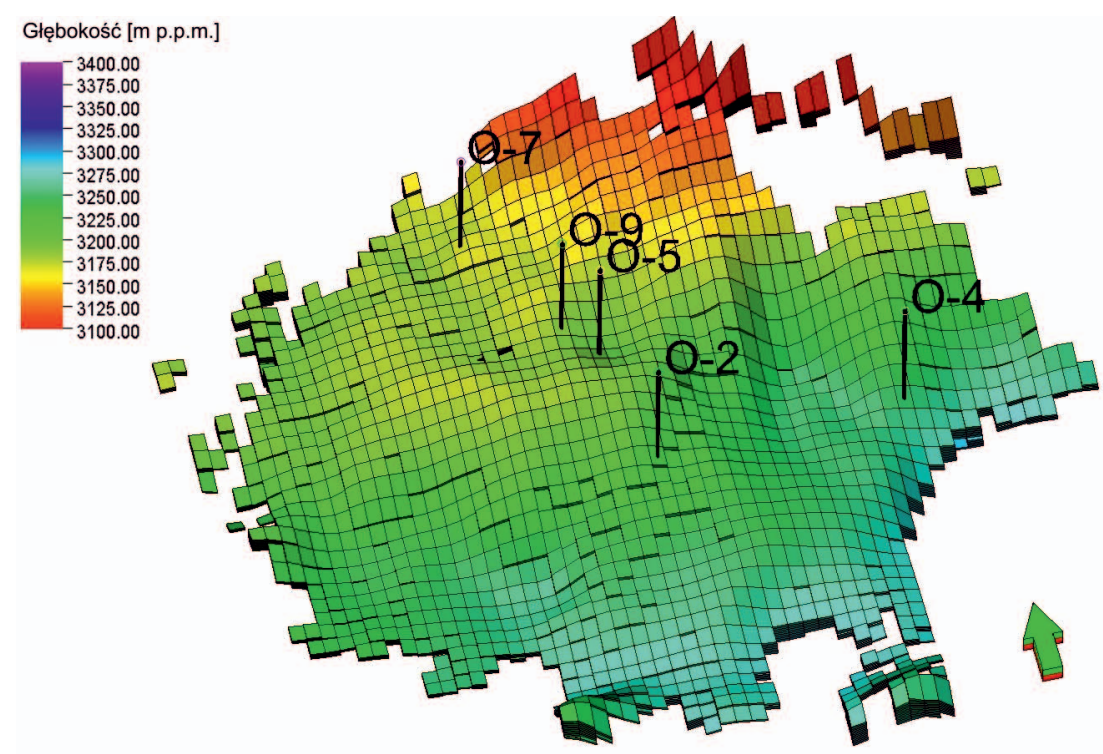

Rys. 4. Widok modelu złoża

Fig. 4. View of the reservoir model 


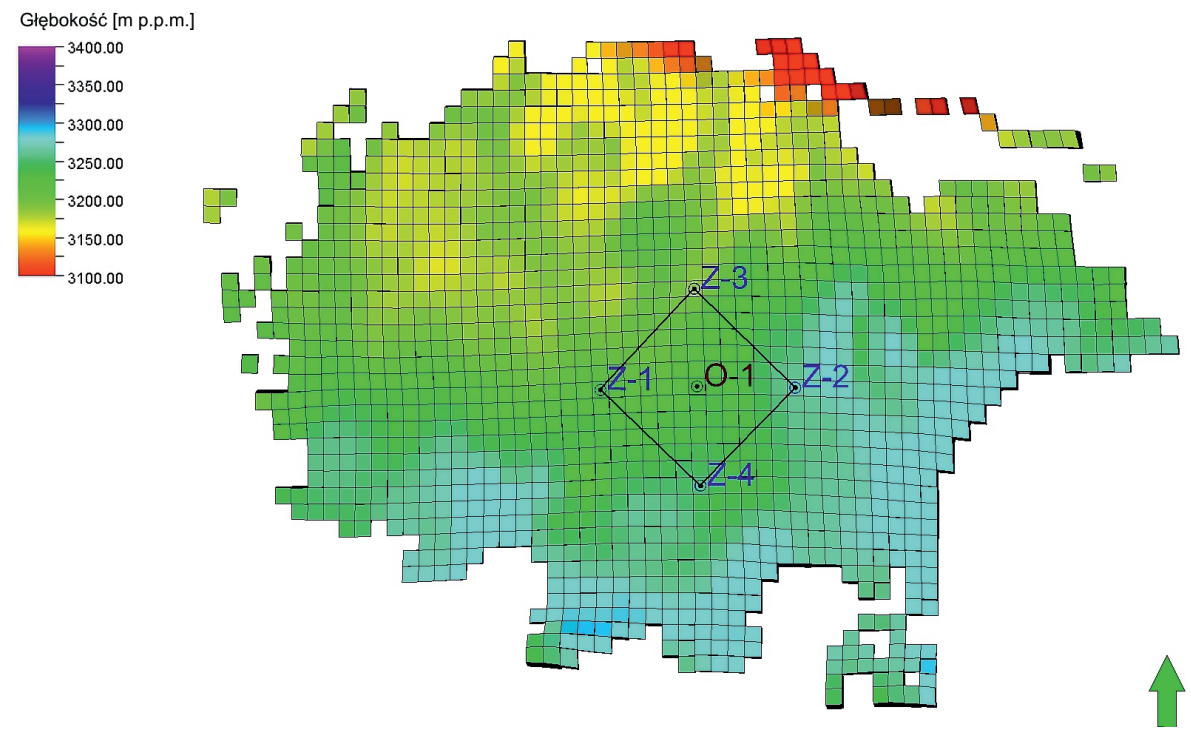

Rys. 5. Odwrócony pięciopunktowy schemat systemu odwiertów

Fig. 5. Inverted five-point scheme of the well system

Rozmiary takiego systemu wynikają z zakładanej ilości wypartej ropy $N_{d i s}$, oraz możliwej do uzyskania wydajności wydobycia ropy $q_{o}$, i czasu trwania procesu wypierania $t_{d i s}$, dla których zachodzi zależność: $N_{d i s}=q_{o} \cdot t_{d i s}$. Docelowa ilość ropy możliwej do wyparcia analizowaną metodą zatłaczania mediów stwarzających warunki wypierania mieszającego dana jest zależnością: $N_{d i s}=V P \cdot S_{o}$, gdzie: $V P$ to całkowita objętość porów wynikająca z rozmiaru zakładanego systemu odwiertów, a $S_{o}$ to średnie nasycenie ropą w złożu przed zastosowaniem analizowanej metody. Tak więc rozmiar systemu odwiertów, określony przez właściwości złoża (porowatość, miąższość, nasycenie ropą), determinuje zdolności wydobywcze i czas trwania analizowanego procesu. Założenie stabilności procesu wypierania, tzn. w przybliżeniu stałe ciśnienie złożowe, determinuje wydajność zatłaczania roztworu chemikaliów do złoża.

Ze względu na znaną ilość ropy w analizowanym obszarze objętym procesem wypierania oraz ograniczony czas $\left(t_{\text {dis }}=16\right.$ lat $)$ stosowania badanej metody można określić wydajność odwiertu wydobywczego niezbędną do sczerpania powyższych zasobów w stopniu odpowiadającym efektywności tej metody (> 80\%). Dla badanych wariantów o powierzchniach 320-720 tys. $\mathrm{m}^{2}$, odpowiadających odległościom pomiędzy każdym z czterech odwiertów zatłaczających a odwiertem wydobywczym wynoszącym 400-600 m, niezbędną wydajność odwiertu wydobywczego oszacowano na $q_{o}=2000 \mathrm{Nm}^{3} / \mathrm{d}$. Wysoka wartość $q_{o}$ wynika przede wszystkim z dużej ilości zasobów ropy (wysokiego nasycenia ropą) możliwej do wydobycia z obszaru objętego procesem wypierania. Wskazuje ona również na niski dotychczasowy stopień sczerpania zasobów, uzyskany metodą eksploatacji pierwotnej.

\section{Zależność efektów wypierania ropy zatlaczanym roztworem $S P C z$ i polimeru od koncentracji SPCZ}

Symulacjami objęto warianty o koncentracji $\mathrm{SPCz}, C_{e}$, z zakresu $1,0-20,0 \mathrm{~kg} / \mathrm{m}^{3}$. Zastosowano stałą koncentrację polimeru, $C_{p}=3,0 \mathrm{~kg} / \mathrm{m}^{3}$. Zatłaczanie przebiegało według schematu: 1 rok zatłaczania wody (solanki) bez chemikaliów, 15 lat zatłaczania roztworu $\mathrm{SPCz}$ i polimeru.

Wyniki symulacji w postaci sumarycznego wydobycia $N_{p}$, i wydajności wydobycia ropy $q_{o}$, przedstawiono na rysunku 6 dla różnych koncentracji SPCz. Rysunek ten pokazuje efekt zwiększonego wydobycia ropy spowodowany zatłaczaniem roztworu SPCz i polimeru. Jednocześnie pozwala on ocenić opóźnienie wzrostu wydobycia ropy w stosunku do rozpoczęcia procesu zatłaczania na około 4 lata - w tym pierwszy rok odnosi się do zatłaczania czystej wody.

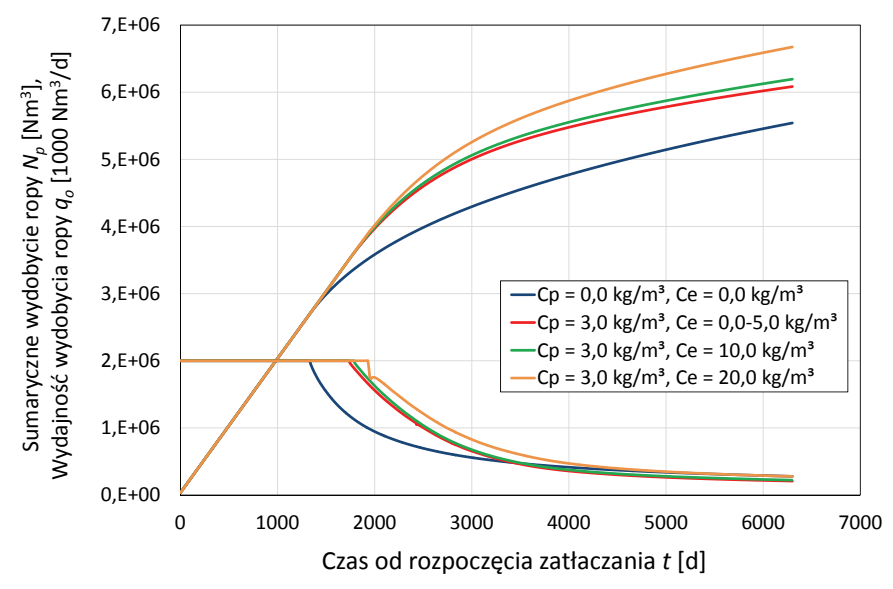

Rys. 6. Sumaryczne wydobycie ropy i wydajność wydobycia ropy dla różnych koncentracji SPCz, $C_{e}$, i polimeru $C_{p}$, utrzymywanych na stałym poziomie podczas testu. Przypadek $C_{e}=0,0-5,0 \mathrm{~kg} / \mathrm{m}^{3}$ oznacza identyczność wyników dla różnych $C_{e}$

Fig. 6. Total oil production and oil production rate for various concentrations of the surfactant, $C_{e}$, and the polymer, $C_{p}$ kept constant during the test. The case $C_{e}=0.0-5.0 \mathrm{~kg} / \mathrm{m}^{3}$ means that the results are identical for different $C_{e}$

Opisane w rozdziale Analiza procesów wypierania ropy przy użyciu wodnych roztworów polimerów i SPCz... mechanizmy wypierania ropy roztworami SPCz i polimeru skutkują w zależnych od czasu i położenia zmniejszonych nasyceniach ropą w analizowanym obszarze. Przykładowe rozkłady tych nasyceń pomiędzy odwiertem zatłaczającym Z-1 a odwiertem wydobywczym O-1 dla wybranej warstwy modelu $(k=10)$ oraz wariantu z koncentracją zatłaczanego SPCz, $C_{e}$, 
wynoszącą $20,0 \mathrm{~kg} / \mathrm{m}^{3}$ przedstawiono na rysunku 7 dla wybranych czasów trwania procesu zatłaczania (z przedziału $t=1-15$ lat). Na koniec omawianego okresu nasycenie to spada do wartości poniżej przyjętej w modelu wartości nasycenia resztkowego ropą dla wypierania niemieszającego $S_{o r}=0,20$. Redukcja ta jest wysoka w pobliżu odwiertu zatłaczającego $\left(S_{o} \approx 0,0\right)$ oraz wyraźnie mniejsza w pobliżu odwiertu wydobywczego $\left(S_{o}=0,12\right)$ i świadczy o obecności i istotnym udziale wypierania mieszającego $\mathrm{w}$ procesie całkowitego wypierania ropy.

Rozkłady lateralne nasyceń ropą w tej warstwie modelu $(k=10)$ i dla tego wariantu pokazano na rysunku 8. Rozkład końcowych nasyceń ropą (rys. 8b) wskazuje efektywny powierzchniowy zasięg wypierania mieszającego, czyli niepełny stopień objęcia analizowanego obszaru zatłaczanym roztworem SPCz i polimeru.

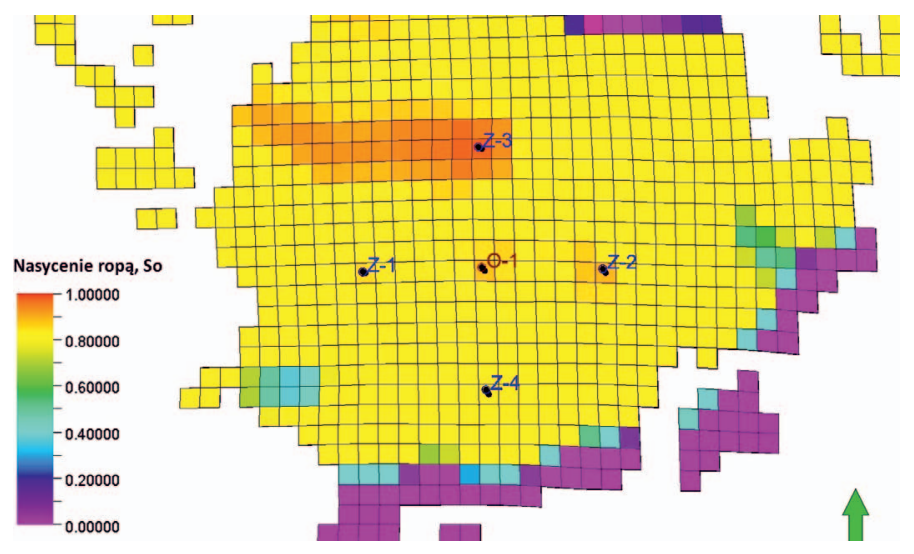

(a) Stan przed rozpoczęciem zatłaczania

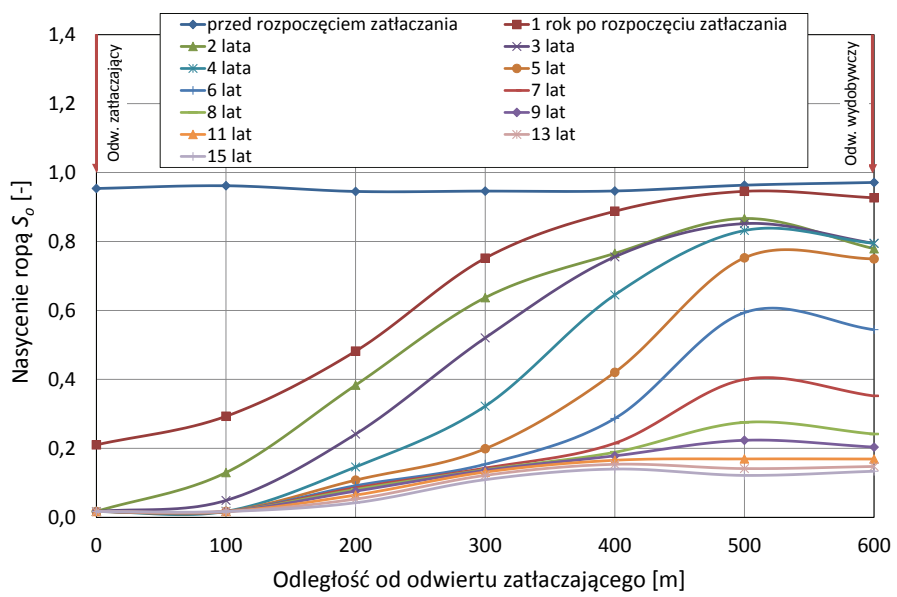

Rys. 7. Rozkład nasyceń ropą pomiędzy odwiertem zatłaczającym i wydobywczym dla różnych czasów zatłaczania

Fig. 7. Distribution of oil saturation between the injection and production wells for different injection times

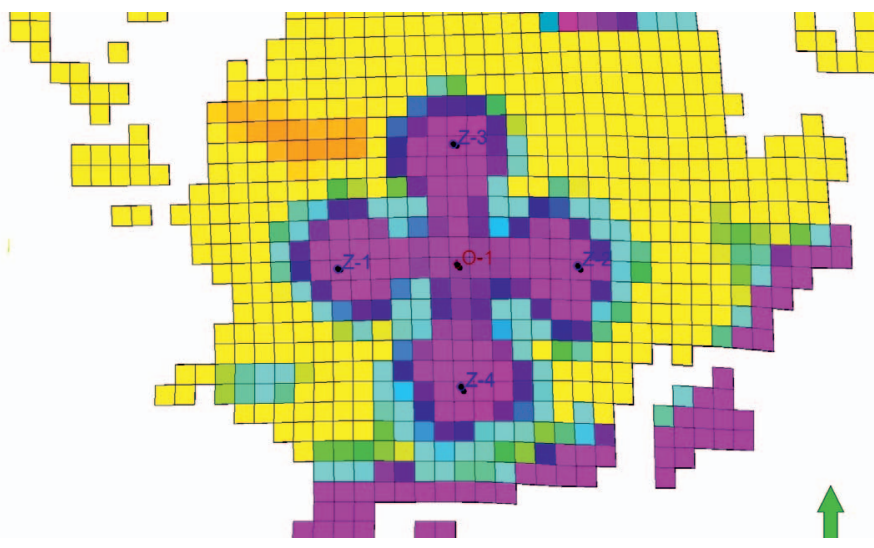

(b) Stan po zakończeniu zatłaczania

Rys. 8. Rozkłady nasycenia ropą w wybranej warstwie $k=10$ modelu dla $C_{e}=20 \mathrm{~kg} / \mathrm{m}^{3}$ i $C_{p}=3,0 \mathrm{~kg} / \mathrm{m}^{3}$

Fig. 8. Distribution of oil saturation in the selected layer $k=10$ of the model for $C_{e}=20 \mathrm{~kg} / \mathrm{m}^{3}$ and $C_{p}=3.0 \mathrm{~kg} / \mathrm{m}^{3}$. a) Before the injection. (b) After the injection

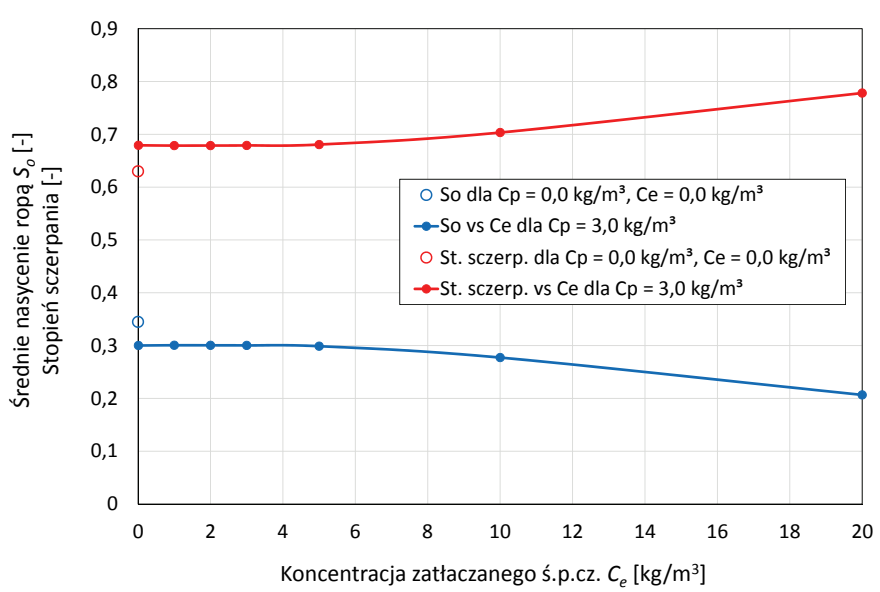

Rys. 9. Sumaryczne wydobycie ropy, średnie końcowe nasycenie ropą w funkcji koncentracji środka powierzchniowo czynnego

Fig. 9. Total oil production, final average oil saturation as a function of surfactant concentration
Stopień sczerpania zasobów ropy oraz średnie końcowe nasycenie ropą $\mathrm{w}$ analizowanym obszarze na koniec symulowanego okresu w funkcji koncentracji środka powierzchniowo czynnego zaprezentowano na rysunku 9. Na rysunku tym przedstawiono również średnie końcowe nasycenie ropą w tym obszarze. Rysunek ten wskazuje na: (i) udział polimeru w zwiększonym sczerpaniu zasobów ropy oraz (ii) efekty zmiennej koncentracji SPCz w zwiększonym sczerpaniu ropy. Efekty te są widoczne dla koncentracji SPCz powyżej $5 \mathrm{~kg} / \mathrm{m}^{3}$.

\section{Zależność efektów wypierania ropy zattaczanym roztworem SPCz i polimeru od czasu ich zattaczania}

Symulowano warianty o stałej koncentracji SPCz, $C_{e}=20,0 \mathrm{~kg} / \mathrm{m}^{3}$, i polimeru, $C_{p}=3,0 \mathrm{~kg} / \mathrm{m}^{3}$. Zatłaczanie przebiegało według schematu: 1 rok zatłaczania wody bez chemikaliów oraz zmienny czas zatłaczania roztworu SPCz i polimeru, $t=1-15$ lat, po którym następował okres zatłaczania 
wody bez chemikaliów, uzupełniający cały proces zatłaczania do 16 lat. Zastosowano pięciopunktowy odwrócony schemat odwiertów (rys. 5).

Wyniki symulacji w postaci sumarycznego wydobycia $N_{p}$, i wydajności wydobycia ropy, $q_{o}$, przedstawiono na rysunku 10 dla różnych czasów zatłaczania roztworu SPCz i polimeru. Obserwuje się wyraźny przyrost wydobycia ropy zwiększający się wraz z wydłużeniem tego czasu. Występuje opóźnienie wzrostu wydobycia ropy w stosunku do rozpoczęcia zatłaczania roztworu chemikaliów.

Pomimo zaprzestania tłoczenia SPCz i polimeru po trzech latach stosowania badanej metody końcowe nasycenie ropą wzdłuż zdefiniowanego powyżej przekroju (rys. 11) wykazuje w pobliżu odwiertu zatłaczającego znaczną redukcję poniżej nasycenia resztkowego ropą dla wypierania niemieszającego, $S_{o r}=0,20$.

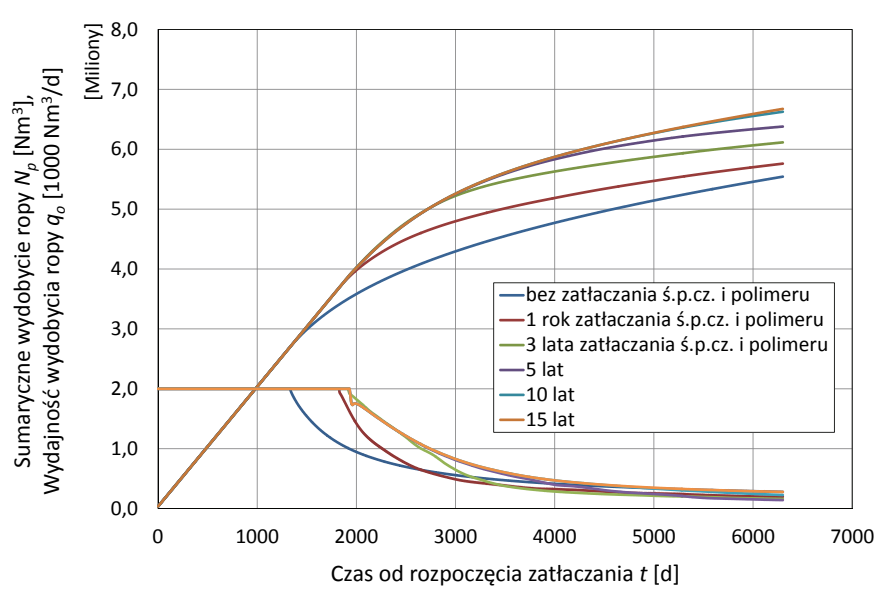

Rys. 10. Sumaryczne wydobycie ropy i wydajność wydobycia ropy dla różnych czasów zatłaczania $\mathrm{SPCz}$ i polimeru

Fig. 10. Total oil production and oil production efficiency rate for various times of surfactant and polymer injection

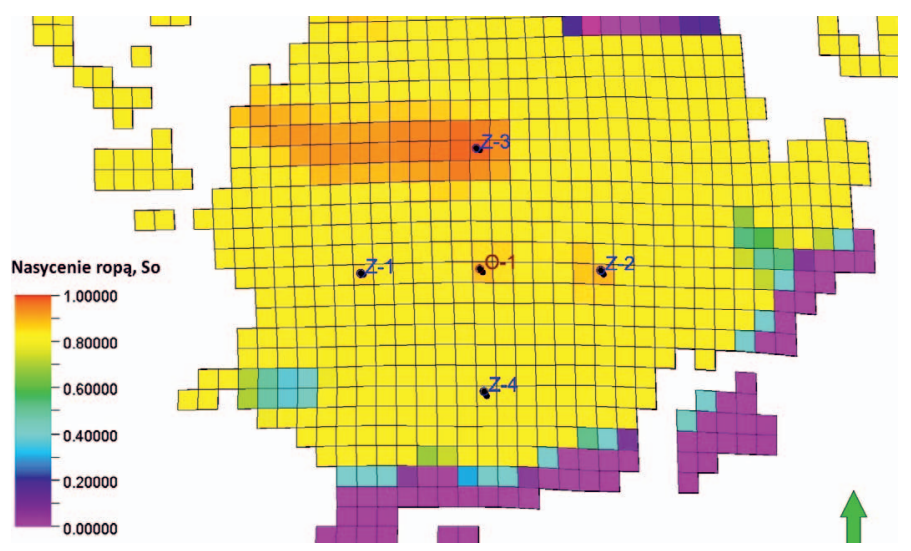

(a) Stan przed rozpoczęciem zatłaczania
Jedynie w pobliżu odwiertu wydobywczego końcowe nasycenie ropą nie spada poniżej tej wartości, chociaż wykazuje znaczną redukcję w stosunku do nasycenia początkowego.

Rozkłady lateralne nasyceń ropą w wybranej warstwie modelu $(k=10)$ pokazano na rysunku 12 dla wariantu z czasem zatłaczania roztworu chemikaliów ograniczonym do trzech lat. Rozkład końcowych nasyceń ropą (rys. 12b) wykazuje bardziej ograniczony powierzchniowy zasięg wypierania mieszającego w porównaniu do wariantu z ciągłym zatłaczaniem roztworu chemikaliów (rys. 8b), wynikający ze zmniejszonego obszaru objętego zatłaczanym roztworem chemikaliów.

Stopień sczerpania ropy oraz średnie nasycenie ropą w analizowanym obszarze na koniec symulowanego okresu w funkcji czasu zatłaczania roztworu chemikaliów przedstawiono na rysunku 13. Wielkości te wykazują monotoniczną zmienność

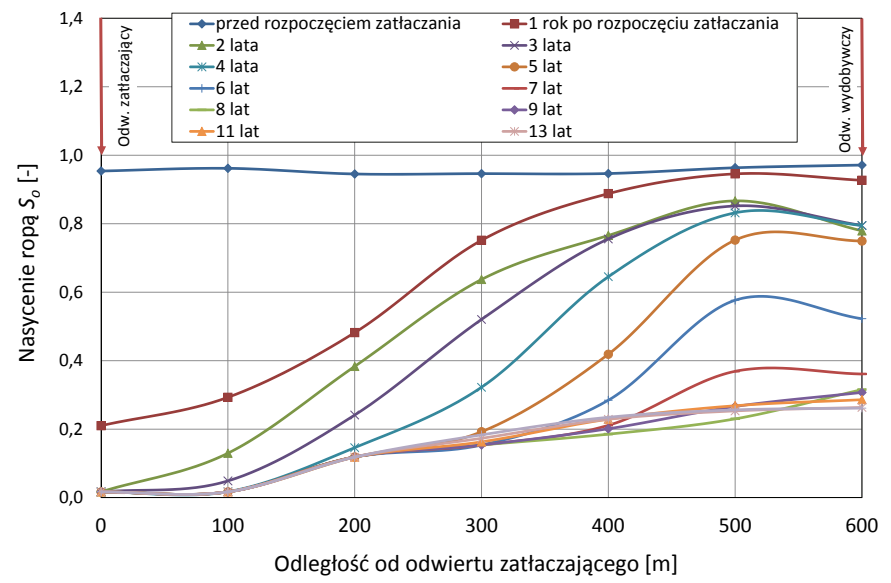

Rys. 11. Rozkład nasyceń ropą pomiędzy odwiertem zatłaczającym i wydobywczym dla wariantu z trzyletnim zatłaczaniem $\mathrm{SPCz}$ i polimeru

Fig. 11. Distribution of oil saturation between the injection and production wells for a scenario with three years of surfactant and polymer injection

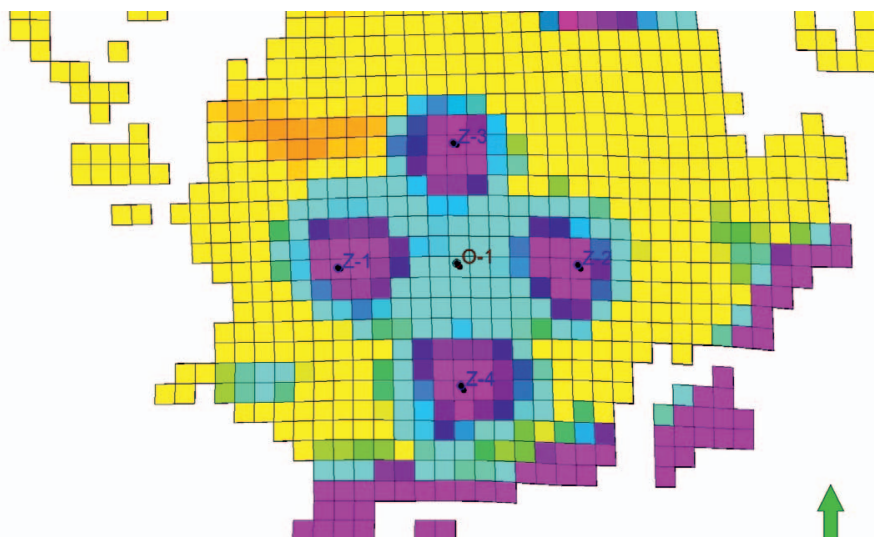

(b) Stan po zakończeniu zatłaczania

Rys. 12. Rozkłady nasycenia ropą w wybranej warstwie $k=10$ modelu dla $C_{e}=20 \mathrm{~kg} / \mathrm{m}^{3}$ i $C_{p}=3,0 \mathrm{~kg} / \mathrm{m}^{3}$ dla wariantu z trzyletnim zatłaczaniem polimeru i SPCz

Fig. 12. Distribution of oil saturation in a selected layer $k=10$ of the model for $C_{e}=20 \mathrm{~kg} / \mathrm{m}^{3}$ and $C_{p}=3.0 \mathrm{~kg} / \mathrm{m}^{3}$ for a scenario with three-year injection of surfactant and polymer injection. (a) Before injection. (b) After injection 
w funkcji czasu zatłaczania i zmienność ta jest największa dla krótkich czasów zatłaczania. Powyżej czasu zatłaczania 10 lat zmienność ta zanika.

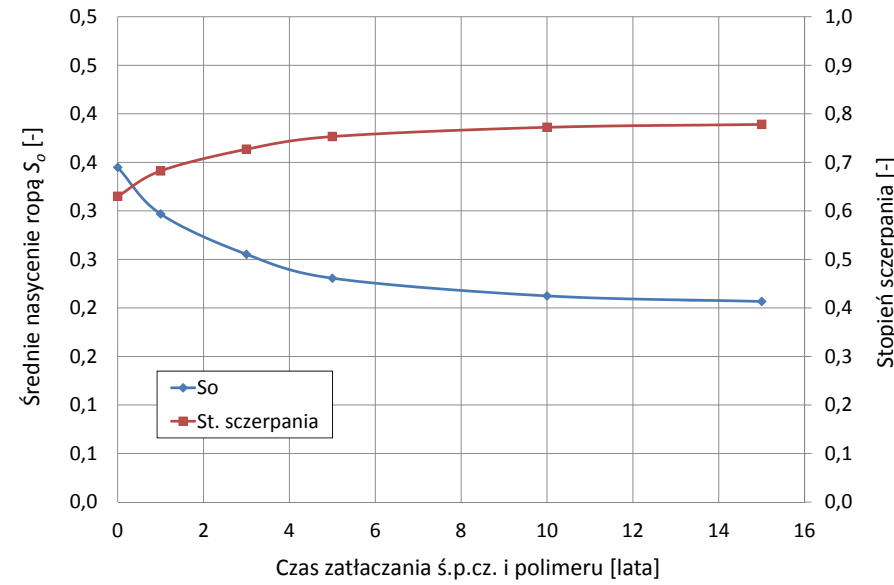

Rys. 13. Sumaryczne wydobycie ropy, średnie końcowe nasycenie ropą w funkcji czasu zatłaczania SPCz i polimeru

Fig. 13. Total oil production, final average oil saturation as a function of surfactant and polymer injection time

\section{Zależność efektów wypierania ropy zatlaczanym roztworem SPCz i polimeru od wielkości obszaru wypierania}

Dotychczasowe analizy wykazują możliwość zwiększenia stopnia sczerpania zasobów ropy analizowaną metodą zatłaczania roztworu SPCz i polimeru jedynie poprzez zwiększenie koncentracji SPCz. Dla użytych charakterystyk mechanizmów wypierania (rozdział Analiza procesów wypierania ropy przy użyciu wodnych roztworów polimerów i SPCz ...) zwiększenie koncentracji zatłaczanego polimeru nie prowadzi do wzrostu stopnia sczerpania zasobów ropy. Podobnie wydłużanie procesu

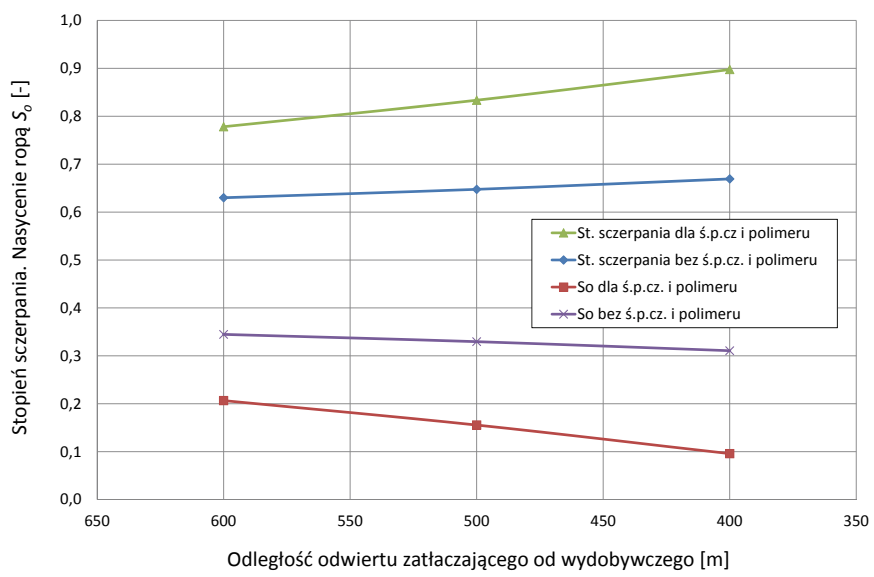

Rys. 14. Stopień sczerpania zasobów ropy w obszarze wypierania, średnie końcowe nasycenie ropą, $S_{o}$, w tym obszarze. Wariant z zatłaczaniem i bez zatłaczania roztworu $\mathrm{SPCz}$ i polimeru

Fig. 14. Depletion coefficient of initial oil in-place in the displacement area, final average oil saturation, $S_{o}$, in this area. A scenario with and without injection of surfactant and polymer wypierania nie stwarza praktycznych możliwości zwiększenia tego stopnia. W przypadku zadanych charakterystyk wydobywczych odwiertów analizowanego złoża nie jest również możliwe osiągnięcie większych wydajności wydobycia ropy i zatłaczania wody, a co za tym idzie - większych ilości SPCz zatłoczonych do złoża w ograniczonym czasie.

Większy stopień sczerpania zasobów ropy można osiągnąć poprzez zmianę lokalizacji odwiertów zatłaczających prowadzącą do efektywnego zmniejszenia obszaru objętego procesem wypierania. Oprócz wariantu analizowanego powyżej (o odległości pomiędzy każdym z 4 odwiertów zatłaczających a odwiertem wydobywczym równej $600 \mathrm{~m}$ ) uwzględniono warianty o odległościach wynoszących $500 \mathrm{~m}$ i $400 \mathrm{~m}$.

Końcowy stopień sczerpania zasobów oraz końcowe średnie nasycenie ropą $\mathrm{w}$ analizowanych obszarach zaprezentowano na rysunku $14 \mathrm{w}$ funkcji odległości pomiędzy odwiertami zatłaczającymi a odwiertem wydobywczym. Dla porównania na rysunku tym przedstawiono analogiczne wielkości dla procesu wypierania z użyciem czystej wody (solanki). Zarówno zatłaczanie czystej wody, jak i roztworów SPCz i polimeru daje końcowy stopień sczerpania zasobów ropy rosnący z redukcją obszaru wypierania. Jednak w przypadku wariantów z roztworem SPCz i polimeru przyrost stopnia sczerpania jest szybszy, sam stopień przyjmuje większe wartości, dochodzące do $90 \%$ zasobów ropy. Ten efekt wzrostu średniego stopnia sczerpania zasobów wynika głównie ze zwiększonego, powierzchniowego stopnia objęcia obszaru wypierania przy jednoczesnym zmniejszaniu się tego obszaru. Stosunkowo wysoki stopień sczerpania zasobów ropy (63-68\%) dla procesu wypierania z użyciem czystej wody (solanki) wynika z długiego czasu eksploatacji (16 lat), dopuszczenia wysokich maksymalnych wykładników

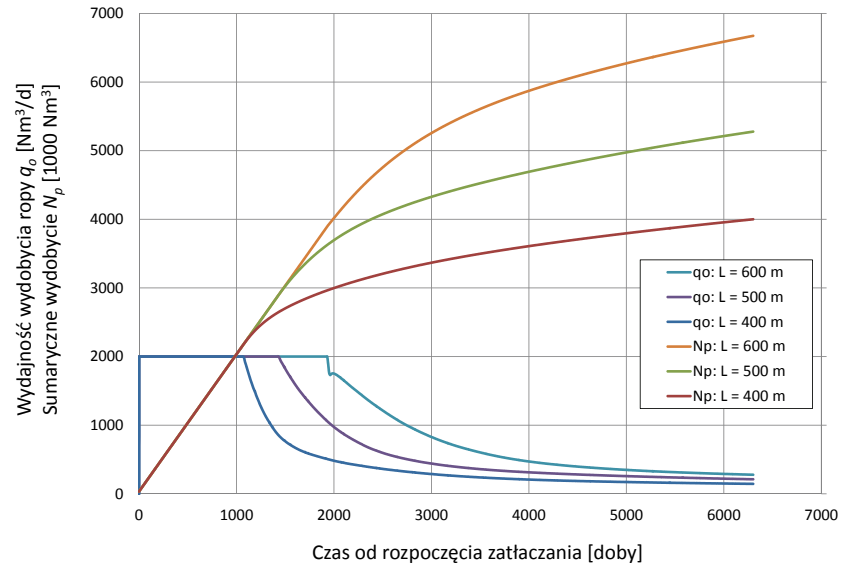

Rys. 15. Sumaryczne wydobycie, $N_{p}$, i wydajność wydobycia, $q_{o}$, ropy w funkcji czasu dla różnych obszarów wypierania $(L-$ odległość odwiertów zatłaczających od odwiertu wydobywczego)

Fig. 15. Total oil production, $\mathrm{N}_{\mathrm{p}}$, and rate, $q_{o}$, oil as a function of time for various displacement areas $(L-$ distance of the injection wells from the production well) 
wodnych $(90 \%)$ oraz relatywnie wysokiego objęcia rozpatrywanego obszaru złoża procesem wypierania dzięki zastosowaniu regularnego schematu lokalizacji odwiertu wydobywczego i odwiertów zatłaczających wodę. Teoretycznie maksymalny stopień sczerpania zasobów ropy w tym procesie wynosi $80 \%$ i wynika z wartości nasycenia ropą resztkową, $S_{o r}=20 \%$. Natomiast stopień sczerpania zasobów ropy (77-90\%) dla procesu wypierania ropy z użyciem roztworu chemikaliów jest dodatkowo konsekwencją osiągnięcia całkowitej redukcji nasycenia ropą resztkową $\left(S_{o r}=0 \%\right)$. Należy zaznaczyć, że osiągnięcie tak wysokiego stopnia sczerpania zasobów jest możliwe dzięki długotrwałemu (przez 16 lat) zatłaczaniu roztworu chemikaliów, co pociąga za sobą wysokie koszty zastosowania omawianej metody. Dlatego realne prognozy wykorzystania tej metody muszą uwzględniać szczegółowy rachunek ekonomiczny.

Należy zwrócić uwagę na fakt, że opisanemu powyżej wzrostowi stopnia sczerpania zasobów ropy nie towarzyszy wzrost wydobycia ropy. Ze względu na malejącą powierzchnię obszaru objętego procesem wypierania obserwuje się spadek sumarycznego wydobycia ropy wraz ze spadkiem wymiarów tego obszaru, co pokazano na rysunku 15 . Tak więc optymalizacja procesu wypierania ropy z analizowanego złoża zależy od przyjętego kryterium optymalizacyjnego.

\section{Podsumowanie i wnioski}

$\mathrm{W}$ pracy przedstawiono efekty symulacji procesu wypierania ropy naftowej przy użyciu wodnego roztworu polimeru i SPCz wykonane na modelu rzeczywistego systemu rdzeni wiertniczych użytego do laboratoryjnych testów procesu wypierania ropy. Model ten zbudowano, wykorzystując rzeczywiste dane ośrodka porowatego rdzeni, właściwości płynów złożowych i mediów wypierających: roztworu solanki, polimeru i SPCz. Proces kalibracji modelu pozwolił odtworzyć wyniki eksperymentu, pozytywnie zweryfikować możliwości modelowania analizowanych procesów za pomocą użytych narzędzi programistycznych oraz uzupełnić brakujące charakterystyki mechanizmów wypierania ropy przez badane roztwory w ośrodku porowatym. W rezultacie otrzymano kompletny zestaw danych wejściowych koniecznych do symulacji procesów wypierania ropy naftowej roztworami polimeru i $\mathrm{SPCz}$ na wielkoskalowych modelach złożowych. Dane te zaimplementowano w modelu krajowego złoża ropy naftowej, na którym przeprowadzono wielokrotne symulacje procesu wypierania ropy. Uzyskano ilościowe wyniki dla różnych parametrów operacyjnych procesu wypierania ropy badanymi roztworami pozwalające ocenić efektywność stosowania analizowanych metod wspomaganego wydobycia ropy.
Symulacje procesu eksploatacji ropy metodą zatłaczania roztworu chemikaliów wykazują dużą efektywność tej metody, wymagającą jednak spełnienia szeregu warunków odnoszących się do operacyjnych parametrów jej użycia. Należą do nich: regularny schemat rozwiercania, duża gęstość siatki odwiertów wydobywczych - zatłaczających, wydłużony okres zatłaczania roztworu chemikaliów i ich stosunkowo wysokie stężenie. Wszystkie te elementy w istotny sposób podnoszą koszty stosowania metody. Dlatego optymalizacja omawianej metody ze względu na korzyści ekonomiczne może znacznie obniżyć jej efektywne wyniki eksploatacyjne (końcowy stopień sczerpania zasobów). Wniosek ten można streścić stwierdzeniem: zasoby przemysłowe stanowią jedynie ułamek zasobów wydobywalnych dla omawianej metody.

Dodatkowy wniosek wynikający z ilościowych rezultatów symulacji omawianej metody w warunkach krajowego złoża ropy oraz z konieczności spełnienia powyższych wymagań dla jej parametrów operacyjnych wskazuje na potrzebę wcześniejszego zastosowania jednej z tzw. metod wtórnych (np. nawadniania złoża) przed użyciem omawianej metody zatłaczania chemikaliów. Takie podejście pozwoli ograniczyć niezbędną wydajność odwiertu wydobywczego, jak również czas zatłaczania i koncentrację zatłaczanych chemikaliów.

Artykuł powstał na podstawie pracy statutowej pt.: Analiza efektów zastosowania chemicznych metod trzecich wspomaganego wydobycia ropy naftowej na przykładzie złoża krajowego w oparciu o wyniki modelowania numerycznego - praca INiG - PIB na zlecenie MNiSW; nr zlecenia: 0029/KZ/2019, nr archiwalny: DK-4100-0019/2019.

\section{Literatura}

Alzayer A., Voskov D., Tchelepi H., 2016. On Modification of Relative Permeability in Compositional Simulation of Nearmiscible Processes. Conference: ECMOR XV-15th European Conference on the Mathematics of Oil Recovery. DOI: 10.3997/2214-4609.201601741.

Delshad M., Han C., Veedu F.K., Pope G.A., 2013. A simplified model for simulations of alkaline-surfactant-polymer floods. Journal of Petroleum Science and Engineering, 108: 1-9.

Fath A.H., Pouranfard A.R., Parandvar R., Pourhadi S., 2016. An investigation of different gas injection scenarios as enhanced condensate recovery method in a naturally fractured gas-condensate reservoir. Petroleum Science and Technology, 34(3): 295-301. DOI: 10.1080/10916466.2015.1098663.

Felber B., 2002. Overview: Tertiary Recovery (January 2002). Society of Petroleum Engineers. DOI: 10.2118/0102-0048-JPT.

Golabi E., 2014. The investigation of the Anionic and Cationic Surfactants effects on the enhanced oil recovery in Iran oil reservoir. International Journal of Chemical Studies, 2(2): 63-71.

Gu J.W., Lu W., Zheng J.P., 2013. Application Research of numerical Simulation in Physical Modeling Displacement Experiments. Advanced Materials Research, 680: 301-306. DOI: 10.4028/ www.scentific.net/AMR.680.301. 
Guo H., Dou M., Hanqing W., Wang F., Yuanyuan G., Yu Z., Yansheng W., Li Y., 2017. Proper Use of Capillary Number in Chemical Flooding. Journal of Chemistry. Article ID 4307368: 11 DOI: $10.1155 / 2017 / 4307368$.

Holm L.W., 1986. Miscibility and Miscible Displacement. Society of Petroleum Engineers. DOI: 10.2118/15794-PA.

Jankovic M.S., 1986. Analytical Miscible Relative Permeability Curves and Their Usage with Compositional and Pseudo-Miscible Simulators. Journal of Canadian Petroleum Technology, 25(4): 11. DOI: $10.2118 / 86-04-07$.

Lubaś J., Szott W., 2012. Projects of Enhanced Gas and Oil Recovery Using $\mathrm{CO}_{2}$ Sequestration Processes in Poland. Nafta-Gaz, 6: 350-358.

Mandal A., 2015. Chemical flood enhanced oil recovery: a review. International Journal of Oil Gas and Coal Technology, 9(3): 241. DOI: 10.1504/IJOGCT.2015.069001.

Mishra S., Bera A., Mandal A., 2014. Effect of Polymer Adsorption on Permeability Reduction in Enhanced Oil Recovery. Journal of Petroleum Engineering, 2014, Article ID 395857: 9. DOI: $10.1155 / 2014 / 395857$.

Mokheimer E., Hamdy M., Abubakar Z., Shakeel R., Habib M.A., Mahmoud M., 2019. A Comprehensive Review of Thermal Enhanced Oil Recovery: Techniques Evaluation. Journal of Energy Resources Technology, 141(3): 18. DOI: 10.1115/1.4041096.

Moreno R., Gonçalves R., Okabe C., Schiozer D., Trevisan O., Bonet E., Iatchuk S., 2011. Comparison of residual oil saturation for water and supercritical $\mathrm{CO}_{2}$ flooding in a long core, with live oil at reservoir conditions. Journal of Porous Media, 14(8): 699-708. DOI: 10.1615/JPorMedia.v14.i8.40.

Ong S.C., Sami A.M., Elhassan M.A., 2019. Numerical Simulation of Alkaline - Surfactant - Polymer Flooding for Enhanced Oil Recovery. International Journal of Innovative Technology and Exploring Engineering, 8(4): 315-320. ISSN: 2278-3075.

Oskarsson H., Uneback I., Hellsten M., 2005. Surfactants as Flow Improvers in Water Injection. Society of Petroleum Engineers. DOI: 10.2118/93116-MS.

Peters E.J., Hardham W.D., 1986. A Comparison of Unstable Miscible and Immiscible Displacements. Society of Petroleum Engineers. DOI: $10.2118 / 19640-\mathrm{MS}$.

Ruben J., Patzek T.W., 2002. Three-Phase Displacement Theory: An Improved Description of Relative Permeabilities. Society of Petroleum Engineers. DOI: 10.2118/77539-MS.

Sheng J.J., Leonhardt B., Azri N., 2015. Status of PolymerFlooding Technology. Society of Petroleum Engineers. DOI: 10.2118/174541-PA.

Sochi T., 2009. Single-phase flow of non-Newtonian fluids in porous media. Thesis of University College London, London: 8-11.
Szott W., 2007. Symulacja laboratoryjnych testów wypierania mieszającego za pomocą symulatora Eclipse Compositional dla polskich złóż ropno-gazowych. Prace Instytutu Nafty $i$ Gazu, 141: 1-50. ISSN 0209-0724.

Szott W., 2012. Bilansowa metoda modelowania wypierania mieszającego. Nafta-Gaz, 12: 965-975.

Szott W., Łętkowski P., Gołąbek A., Miłek K., 2012. Ocena efektów wspomaganego wydobycia ropy naftowej i gazu ziemnego $\mathrm{z}$ wybranych złóż krajowych z zastosowaniem zatłaczania $\mathrm{CO}_{2}$. Prace Naukowe Instytutu Nafty i Gazu, 184: 1-35. ISSN 0209-0724.

Szott W., Miłek K., 2015. Zastosowanie symulacji złożowych do analizy porównawczej procesu EOR na przykładzie wybranych metod wspomagania. Nafta-Gaz, 3: 167-176.

Wilk K., Wojnicki M., Kasza P., Warnecki M., Czupski M., Masłowski M., Moska R., 2019. Cooperation between INiG - PIB and PGNiG in the field of increasing oil recovery efficiency from polish mature reservoirs. Praca własna Zakładu Stymulacji Wydobycia Weglowodorów, Instytutu Nafty i Gazu - Państwowego Instytutu Badawczego przedstawiona na HC Increasing Recovery Efficiency in the Mature Fields. Methods \& Technology for Cooperation, WPC Expert Workshop, 21-22 October 2019, Bucharest, Romania.

Wuensche R., 1987. Nitrogen Injection for Enhanced Oil Recovery. Petroleum Society of Canada. DOI: 10.2118/78-29-44.

Xiong L., Huang Y., Wu Y., Gao C., Gao W., 2018. Study on the Influence of Inaccessible Pore Volume of Polymer Development. IOP Conference Series: Earth and Environmental Science, 170(2): 022045. DOI: 10.1088/1755-1315/170/2/022045.

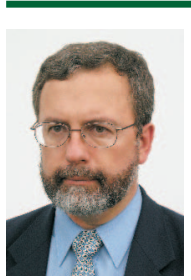

Dr Wiesław SZOTT

Adiunkt; kierownik Zakładu Symulacji Złóż

Węglowodorów i Podziemnych Magazynów Gazu

Instytut Nafty i Gazu - Państwowy Instytut Badawczy

ul. Lubicz 25 A

31-503 Kraków

E-mail: wieslaw.szott@inig.pl

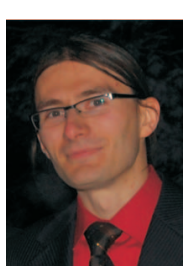

Mgr inż. Krzysztof MIŁEK

Asystent w Zakładzie Symulacji Złóż Węglowodorów i Podziemnych Magazynów Gazu

Instytut Nafty i Gazu - Państwowy Instytut Badawczy

ul. Lubicz 25 A

31-503 Kraków

E-mail:krzysztof.milek@inig.pl 